\title{
La orientación emprendedora del fundador y el éxito en la internacionalización de la empresa
}

\author{
Francisco Javier Forcadell ${ }^{\mathrm{a}}$ y Fernando Úbeda ${ }^{1 \mathrm{~b}}$ \\ ${ }^{a}$ Universidad Rey Juan Carlos, España \\ ${ }^{b}$ Universidad Autónoma de Madrid, España
}

doi: $10.20420 /$ eni.2021.425

\begin{abstract}
Resumen
Este artículo analiza el papel que juega la orientación emprendedora individual (OEI) en el éxito de las iniciativas empresariales internacionales. Además, argumentamos que la experiencia emprendedora constituye una de las principales fuentes de OEI. Las hipótesis se analizan empíricamente utilizando un panel de 22 años de pymes familiares. Nuestros resultados confirman las hipótesis y proporcionan una mejor comprensión del papel de la OEI en el éxito de estrategias corporativas como la internacionalización. Específicamente, la OEI mejora indirectamente el desempeño de la empresa al aumentar la velocidad de internacionalización.
\end{abstract}

Palabras clave: orientación emprendedora, emprendimiento internacional, experiencia emprendedora, resultados, empresa familiar.

Clasificación JEL: L26, M16.

Fuente de referencia: Forcadell, F.J., \& Úbeda, F. (2020). Individual entrepreneurial orientation and performance: the mediating role of international entrepreneurship. International Entrepreneurship and Management Journal. DOI. https://doi.org/10.1007/s11365-020-00693-81-26.

\section{Introducción}

El concepto de orientación emprendedora (OE), o los procesos de elaboración de estrategias que proporcionan a las organizaciones una base para las decisiones y acciones emprendedoras (Rauch y otros, 2009), es ampliamente considerado una piedra angular de la literatura sobre emprendimiento. La OE se ha definido y operacionalizado tradicionalmente a nivel de empresa (Covin y otros, 2020), ejerciendo un efecto positivo en el desempeño. La orientación emprendedora individual (OEI) son aquellas características o actitudes personales subyacentes que poseen los individuos que los llevan a emprender actividades emprendedoras (Bolton \& Lane, 2012). En este artículo, identificamos el efecto indirecto de la OEI sobre el desempeño a través de la acción emprendedora internacional. Analizamos un panel de 22 años de pequeñas y medianas empresas (PYMES) familiares. Al hacerlo, ponemos de manifiesto la importancia de la experiencia emprendedora en la configuración de la OEI.

\section{Experiencia emprendedora, emprendimiento internacional y resultado empresarial}

La OEI es un recurso intangible que determina diferencias en el resultado de la empresa. La heterogeneidad a nivel de individuo incluye todos los tipos de características personales relativamente estables que pueden ser importantes para comprender el comportamiento en un determinado contexto, incluida la personalidad, los valores, las creencias, las experiencias y las características demográficas. Los recursos humanos constituyen la principal fuente de heterogeneidad individual. La literatura sobre emprendimiento considera que el emprendedor y sus características (por ejemplo, OEI) son el principal recurso humano que poseen las empresas. El emprendedor genera riqueza económica mediante la explotación de

1'Autor de correspondencia: fernando.ubeda@uam.es. 
oportunidades empresariales. El emprendimiento estratégico efectivo requiere que los líderes organizacionales adquieran, organicen $y$ desplieguen recursos para explorar y explotar las oportunidades emprendedoras.

Sin embargo, la sola presencia de una disposición emprendedora no garantiza que dichos comportamientos se manifiesten. Los comportamientos de los ejecutivos son el resultado de su personalidad, experiencia y valores (es decir, disposiciones). La experiencia previa en emprendimientos es esencial, es decir, experiencia en la actividad emprendedora, o experiencias pasadas de emprendimiento relacionadas con la propia fundación de una empresa.

En el caso del fundador de la empresa, su experiencia emprendedora determina actitudes y comportamientos emprendedores. Algunos estudios encuentran una relación positiva entre las empresas dirigidas por los propios fundadores y su rendimiento y supervivencia, así como la internacionalización. Algunos argumentos para vincular el comportamiento del fundador con la OEI provienen la Teoría del Stewardship, en la que el administrador busca lograr los objetivos de la organización (por ejemplo, crecimiento o rentabilidad) más allá de sus intereses. Los directores ejecutivos que también son fundadores de pymes, son administradores que tienen más probabilidades de favorecer las actividades de riesgo, proactivas e innovadoras. Esta teoría argumenta que los fundadores tienen una mayor motivación intrínseca, pasión, experiencia específica, un enfoque a largo plazo, una identificación organizacional más fuerte y un compromiso más destacado con la empresa. Es más probable que los fundadores inviertan tiempo, esfuerzo y riesgo porque se identifican más con la creación de la empresa.

En resumen, la experiencia emprendedora implica una serie de actividades inherentes al desarrollo de una mentalidad emprendedora, que incluyen la alta asunción de riesgos, la innovación y la proactividad (las dimensiones de la OEI). En el caso de la innovación, los fundadores tienden a invertir más en Investigación y Desarrollo (I+D) en comparación con sus pares no fundadores. La experiencia emprendedora influye positivamente en las nuevas empresas, especialmente en las basadas en tecnología. En cuanto a la dimensión de la toma de riesgos, los empresarios exitosos ven oportunidades en situaciones en las que otras personas tienden a ver riesgos. Con respecto a la proactividad, los empresarios pueden tener más probabilidades que otras personas de descubrir oportunidades porque es menos probable que se involucren en un pensamiento contrafáctico, menos probabilidades de sentir arrepentimiento por las oportunidades perdidas y son menos susceptibles a la inercia de la inacción.

Consideramos que la OEI impulsa los movimientos emprendedores (es decir, el espíritu empresarial internacional), mejorando el resultado de la empresa. Por lo tanto, sugerimos un efecto indirecto de la OEI sobre el desempeño a través del emprendimiento internacional. Entre las diferentes causas del emprendimiento internacional, la OEI juega un papel determinante. Entre los diferentes recursos necesarios para el emprendimiento internacional, los rasgos del emprendedor son fundamentales. Las características emprendedoras, como el comportamiento innovador, proactivo y de búsqueda de riesgos (dimensiones de la OEI), pueden determinar la internacionalización y la velocidad a la que se produce.

\section{Análisis empírico}

Utilizamos la Encuesta de Estrategias Empresariales para un periodo de 22 años (1990 a 2011), que realiza anualmente la Fundación SEPI, para una muestra de empresas manufactureras españolas. Seleccionamos una muestra de pymes familiares que iniciaron su actividad internacional exportando entre $1990 \mathrm{y}$ 
2008. Además, dicha actividad exportadora se mantuvo de forma permanente durante al menos tres años consecutivos. Esta condición nos permite excluir al exportador puntual o esporádico. Analizamos el efecto del emprendimiento internacional sobre el desempeño durante los primeros diez años de actividad exportadora. Nuestra muestra final incluye 225 empresas familiares, cada una de las cuales tiene menos de 250 empleados. Esto da como resultado un panel desequilibrado de 1.235 observaciones. Consideramos empresa familiar a aquellas empresas en las que uno o más miembros de la familia ocupan puestos directivos superiores.

\section{Conclusiones}

Encontramos evidencia empírica para nuestras hipótesis que vinculan OEI, emprendimiento internacional y desempeño para un panel de pymes familiares. Concretamente, confirmamos el papel mediador del emprendimiento internacional entre la OEI y el resultado. La OEI del emprendedor es determinante en el éxito de aquellas pymes que realizan un movimiento emprendedor internacional. Aquellas pymes familiares gestionadas por emprendedores con alta OEI logran una mayor velocidad de internacionalización, lo que favorece el efecto positivo de la internacionalización en el desempeño de las empresas. Por lo tanto, la OEI mejora los resultados de las empresas de manera indirecta al aumentar la velocidad de internacionalización. Nuestro trabajo destaca algunos vínculos entre la OEI del empresario, la decisión de internacionalizarse y sus consecuencias en los resultados de la empresa. Nuestros resultados empíricos sugieren que la OEI: 1) permite una mejor explotación de los recursos de la empresa que respaldan la actividad internacional; y 2) mejora la identificación y explotación de oportunidades internacionales, apalancando los resultados de la empresa.

\section{Referencias}

Bolton, D.L., \& Lane, M.D. (2012). Individual entrepreneurial orientation: Development of a measurement instrument. Education + Training, $54(2 / 3), 219-233$.

Covin, J.G., Rigtering, J.C., Hughes, M., Kraus, S., Cheng, C.F., \& Bouncken, R.B. (2020). Individual and team entrepreneurial orientation: Scale development and configurations for success. Journal of Business Research, 112, 1-12.

Rauch, A.J., Wiklund, J., Lumpkin, G.T., \& Frese, M. (2009). Emprendedora orientation and business performance: An assessment of past research and suggestions for the future. Entrepreneurship Theory and Practice, 33, 761-788. 


\title{
Founder's entrepreneurial orientation and success in the firm's internationalization
}

\author{
Francisco Javier Forcadella ${ }^{\mathrm{a}}$ F Fernando Úbeda ${ }^{1 \mathrm{~b}}$ \\ ${ }^{a}$ Universidad Rey Juan Carlos, Spain \\ ${ }^{b}$ Universidad Autónoma de Madrid, Spain
}

doi: $10.20420 /$ eni.2021.425

\begin{abstract}
This paper analyses the role that individual entrepreneurial orientation (IEO) plays in the success of international entrepreneurship moves. Additionally, we argue that entrepreneurial experience constitutes one of the primary sources of IEO. The hypotheses are empirically analysed using a 22-year panel of family SMEs. Our results confirm the hypotheses and provide a better understanding of the role of IEO in the success of corporate strategies such as internationalisation. Specifically, IEO indirectly improves firm performance by increasing internationalisation speed.
\end{abstract}

Keywords: Entrepreneurial orientation, international entrepreneurship, entrepreneurial experience, performance, family firm.

JEL classification: L26, M16.

Reference source: Forcadell, F. J., \& Úbeda, F. (2020). Individual entrepreneurial orientation and performance: the mediating role of international entrepreneurship. International Entrepreneurship and Management Journal. DOI. https://doi.org/10.1007/s11365-020-00693-81-26.

\section{Introduction}

The concept of entrepreneurial orientation (EO), or 'the strategy-making processes that provide organisations with a basis for entrepreneurial decisions and actions' (Rauch and others, 2009: 762), is widely considered a cornerstone of the entrepreneurship literature. EO has traditionally been defined and operationalised at the firm level (Covin and others, 2020), exercising a positive effect on performance. Bolton and Lane (2012: 221) define individual entrepreneurial orientation (IEO) as the underlying 'personal characteristics or attitudes' that individuals possess that lead them to undertake entrepreneurial activities. In this paper, we identify the indirect effect of IEO on performance through international entrepreneurship. We analyse a 22-year panel of family small and medium-sized enterprises (SMEs). In doing so, we account for the importance of entrepreneurial experience in shaping IEO.

\section{Entrepreneurial experience, international entrepreneurship, and firm performance}

IEO is an intangible resource that determines differences in firm performance. Heterogeneity is applicable at different levels, from firm-level to individual level. In particular, individual heterogeneity includes all types of relatively stable individual characteristics that might be salient in understanding behaviour in the specific context at hand, including personality, values, beliefs, experiences and demographic features. Literature has traditionally highlighted that human resources constitute the primary source of individual heterogeneity. The entrepreneurship literature considers that the entrepreneur and their characteristics (e.g. IEO) are the primary human resource possessed by firms. The entrepreneur generates economic wealth by exploiting entrepreneurship opportunities.

${ }^{1}$ Corresponding author: fernando.ubeda@uam.es. 
Effective strategic entrepreneurship requires organisational leaders to acquire, organise, and deploy resources to explore and exploit entrepreneurial opportunities.

Nevertheless, the sole presence of a disposition to engage in entrepreneurial behaviours does not guarantee that such behaviours will manifest. Executives' behaviours result from their personality, experience, and values (i.e. dispositions). Previous experience on ventures is essential, i.e. experience on entrepreneurial activity, or past entrepreneurial experiences in founding a business.

In the case of the firm founder, their entrepreneurial experience determines entrepreneurial attitudes and behaviour. Some studies find a positive relationship between firms run by founders and performance and firm, high growth, and initial internationalisation. Some arguments for linking founder behaviour to IEO comes from stewardship theory, in which the steward seeks to achieve the objectives of the organisation (e.g. growth or profitability) beyond their interests. Chief Executive Officers (CEOs) that are also founders of SMEs, are stewards who are more likely to favour risky, proactive, and innovative. These authors argue that founderCEOs have greater intrinsic motivation, passion, firm-specific expertise, a long-term approach, stronger organisational identification, and a more outstanding commitment to the firm. Founders are more likely to invest time, effort, and risk because they identify themselves more strongly with the firm's creation.

In summary, entrepreneurial experience entails a series of activities inherent to developing an entrepreneurial mindset, including high risk-taking, innovativeness, and proactiveness (the dimensions of IEO). In the case of innovativeness, founder-CEOs tend to invest more in Research and Development (R\&D) compared to their non-founder peers. Previous literature found that entrepreneurial experience positively influences new ventures, especially new technology-based ventures. Regarding the risk-taking dimension, successful entrepreneurs can see opportunities in situations where other people tend to see risks. Regarding proactiveness, entrepreneurs may be more likely than other persons to discover opportunities because they are less likely to engage in counterfactual thinking, less likely to experience regret over missed opportunities, and are less susceptible to inaction inertia.

We argue that IEO resource drives entrepreneurial moves (i.e. international entrepreneurship), improving firm performance. Thus, we suggest an indirect effect of IEO on performance through international entrepreneurship. Among the different causes of international entrepreneurship, IEO plays a determinant role. The resource-based theory considers resources essential for entrepreneurial activities. Among the different heterogeneous resources needed for international entrepreneurship, the entrepreneur's traits are essential. Entrepreneurial characteristics, such as innovative, proactive, and risk-seeking behaviour (dimensions of IEO), may shape internationalisation and the speed at which it occurs.

\section{Empirical analysis}

We use the Survey on Business Strategies for 22 years (1990 to 2011), conducted by the SEPI Foundation annually, for a sample of Spanish manufacturing firms. We select a sample of family SMEs that began their international activity by exporting from 1990 to 2008 and then continued exporting permanently for at least three consecutive years. This condition allows us to exclude the punctual or sporadic exporter. We analyse the effect of international entrepreneurship on performance during the first ten years of export activity. Our final sample includes 225 family firms that each have fewer than 250 employees. This results in an 
unbalanced panel of 1,235 observations. The definition of a family firm is controversial because a consensus has not yet been reached in the family firm literature. We consider a family firm to be those firms in which one or more family members occupy top managerial positions.

\section{Conclusions}

We find empirical evidence for our hypotheses linking IEO, international entrepreneurship and performance for a panel of family SMEs. Specifically, we confirm the mediating role of international entrepreneurship between IEO and performance. The entrepreneur's IEO is determinant in the success of those SMEs making an international entrepreneurial move. Those family SMEs managed by entrepreneurs with high IEO achieve a higher internationalisation speed, which furthers the positive effect of internationalisation on firm performance. Thus, IEO improves firm performance indirectly by increasing the speed of internationalisation.

Our study contributes to the literature by completing the picture sketched by previous studies analysing IEO and therefore improves our understanding of the underlying mechanisms explaining the effect of IEO on performance previously identified in the literature. The value of IEO emerges from the effect of the strategies and moves made by the firm (i.e. international entrepreneurship). In other words, IEO constitutes a valuable, heterogeneous, individual-level resource that generates valuable heterogeneous firm-level resources.
We have contributed to the literature by extending international entrepreneurship theory from the entrepreneurship side, offering a more complete view of the causes and consequences of international entrepreneurship. Specifically, our paper highlights some linkages between entrepreneur IEO, the firm-level decision to internationalise, and its consequence on firm performance. Our empirical results suggest that IEO: 1) enables better exploitation of firm resources supporting international activity; and 2) improves the identification and exploitation of international opportunities, leveraging firm performance. Thus, we contribute to the internationalisation literature that focuses on the influence of management characteristics on the success of the internationalisation of SMEs. We also contribute to understanding how IEO explains the heterogeneity of family firms. In particular, our results contribute to the literature by extending our understanding of the role of IEO in shaping international entrepreneurship in the context of family firms.

\section{References}

Bolton, D.L., \& Lane, M.D. (2012). Individual entrepreneurial orientation: Development of a measurement instrument. Education + Training, 54(2/3), 219-233.

Covin, J.G., Rigtering, J.C., Hughes, M., Kraus, S., Cheng, C.F., \& Bouncken, R.B. (2020). Individual and team entrepreneurial orientation: Scale development and configurations for success. Journal of Business Research, 112, 1-12.

Rauch, A.J., Wiklund, J., Lumpkin, G.T., \& Frese, M. (2009). Entrepreneurial orientation and business performance: An assessment of past research and suggestions for the future. Entrepreneurship Theory and Practice, 33, 761-788. 